FACTA UNIVERSITATIS

Series: Teaching, Learning and Teacher Education Vol. 3, No 1, 2019, pp. 31 - 39

https://doi.org/10.22190/FUTLTE1901031M

Original research paper

\title{
REPRESENTATION OF ECOLOGICAL CONTENTS IN EDUCATION AND ASSESSMENT IN LOWER GRADES OF PRIMARY SCHOOL
}

UDC 37.033:502.131.1 502/504

\author{
Ljiljana Mitić \\ Pedagogical Faculty in Vranje, University of Niš, Serbia
}

\begin{abstract}
The subject matter of this research is the representation of ecological contents in teaching in junior primary school and not only does it have practical application, but also theoretical. The ecological contents of teaching in junior primary school are directed towards the education of students and their development for the improvement of their immediate environment. In order to successfully approach the improvement in teaching lower grade students in primary school, regarding ecological contents, it is necessary first to examine and determine how many of our schools are represented. The aim and task of the research was to point out the importance of ecological contents and their representation in teaching in junior primary school. Accordingly, the paper presents a part of the research that shows what teachers think about the representation of ecological contents in the classroom. The research has shown that this is a very important topic.
\end{abstract}

Key words: ecological contents, ecological education, environment, teacher

\section{INTRODUCTION}

Raising environmental awareness and knowing the necessity of preserving the environment emphasizes the need for active participation and concrete actions for the purpose of its protection and improvement. We cannot protect the environment only by passing and implementing laws, by reducing pollution, but also by raising awareness of citizens about the importance of protecting and conserving natural resources, especially with young people.

In order to form an ecological way of thinking, ecological education and upbringing should start an early age; hence, a very important role in acquiring such knowledge is

Received March 14, 2019/Accepted June 05, 2019

Corresponding author: Ljiljana Mitić

Pedagogical Faculty in Vranje, University of Niš, Partizanska 14, 17500 Vranje, Serbia

Phone: +381 17421633 •E-mail: ljiljanam@pfvr.ni.ac.rs 
primary school. The task of ecological education in elementary school is to acquire knowledge, so that the generations that come will have the knowledge to participate more actively in solving the problems of of polluting the environment environment. In order to expect from them to behave responsibly to the environment, it is necessary to educate them, which is possible only by introducing ecological contents into all levels of education and upbringing. Primary school continues with ecological education and upbringing started in the family and preschool institutions. Primary school curriculum enables the incorporation of ecological contents (in all subjects and all grades) from their native language, knowledge of nature and society, to art and music education. Not only does primary school provide significant opportunities for acquiring certain knowledge, It also helps forming certain habits for raising ecological awareness, developing love and responsible attitude towards nature. By incorporating ecological contents into the curricula of particular subjects, they become an integral part of the wider picture, its inseparable part. Ecological contents should ensure that primary school students learn about the basic phenomena (the notion of disturbing ecological balance and the notion of degradation of the environment) and to gain knowledge about the negative effects of air, water, and noise pollution on human health.

In addition to the introduction of new ecological contents into the curricula, it is necessary to process ecological contents thematically, both within the subject matter and, in particular, by linking contents from different subjects on the basis of common themes. Very seriously and efficiently, we need to arrive at organized and innovative various ways of updating existing plans and programs of teaching and introducing ecological contents through special subjects and within the existing subjects.

\section{ECOlOGICAL CONTENTS IN SUBJECTS IN JUNIOR PRIMARY SCHOOL}

In schools, there is no single subject that deals with environmental issues; instead, those issues are studied in a number of cases and, unfortunately, even in those cases where ecological topics are encountered, they often fail to to be addressed in the most adequate way.

Ecological contents are intertwined through all subjects, by correlation, and are mostly represented in subjects like "The World Around Us" and "Nature and Society" in lower grades of primary school. The primary objective of "The World around Us" course is for children of that age to introduce themselves, learn something about their environment and develop the ability to lead an environmentally responsible life, and raise environmental awareness of their immediate environment. In the subject "The World Around Us" for the first and second grade of primary school, the most important goals are the formation of elementary notions as regards natural and social sciences, stimulation and development of children's interests, and their ability to ask questions, form ideas and give responses regarding the phenomenon of the environment, development of research activities, free expression of their observations, and anticipation, development of a responsible attitude of children towards themselves, the environment in which they live and respect for others. The $i$ of these goals should be sought through the implementation and introduction of new ecological contents of the subject "The World Around Us" that deals with the phenomena and processes in our immediate environment. The goal in the curriculum "Nature and Society" in the third and fourth grade is for students to learn about themselves, their environment and develop the ability for a responsible life in it. The goals set are implemented through concrete tasks of the curriculum, which aims at acquiring scientific literacy, developing the ability to observe natural phenomena and processes in the environment and to see their connection. 
Ecological contents should ensure that pupils in lower grades of primary school become familiar with the basic concepts of environmental disbalance and environmental degradation, to gain knowledge of negative effects of air, soil, and water pollution, prevention and protection against adverse effects. Students should be trained to actively learn about the condition of the environment, to know the principle of causality in the environment by performing simple experiments, to be encourage to behave responsibly towards the living world, to rationally use natural resources, to have responsibilities, healthy attitude towards oneself, to solve problems individually and in teams, all of which are necessary for forming the right attitude and for critical thinking.

However a question arises whether we should demand the school to be the most responsible link for teaching and acquiring environmental knowledge. How big is its power? Is it enough to have ecological contents only in theory? Are existing ecological contents sufficient for one to acquire basic ecology knowledge? The school can have a significant impact if the curricula are created in accordance with requirements and standards of a modern society that meet the needs and abilities of children. Andevski (1997) emphasizes that there is a justifiable suspicion that the school is lagging behind its time and that frequent changes happen much faster than the school can follow, and that it takes a long time to enter new contents in schools, to apply new methods, and new forms of work.

The modernization of curricula in the field of ecological education and education is one of the most important tasks of environmental education. The results of previous research show that existing contents in our school system do not meet the needs of quality and efficient ecological education (Nedeljković, 2005).

\section{METHODOLOGY OF RESEARCH}

\subsection{Subject research}

The choice of contents of ecological education and education and the modelling of adequate teaching programs is defined by many factors, among which is the representation of ecological contents in education and education in junior primary school, primarily through science subjects, as well as the modelling of special programs. Namely, in the curriculum of ecological education and teaching students those ecological contents in lower grades of primary school, there are also some values the society expects students to adopt. The complex problem of choosing the right ecological contents in teaching lower grades in primary school is adressed from the aspect of determining the representation of ecological contents choices, with the aim of modeling adequate curricula in which ecological contents would be represented. Therefore, the subject matter of our research is the representation of ecological contents in classes in junior primary school and the determination of ecological contents that should be included in the curricula of ecological education of students. The research was carried out on two occasions, although from a different aspect, and the main goal of the research was to determine the representation of ecological contents in junior primary school.

\subsection{The objective and tasks of the research}

The aim of this research is to determine, based on the attitudes and opinions of teachers, which ecological contents should be included in the curriculum of ecological education and education of students in junior primary school, in order to improve the quality and results of 
ducational process in this field on the basis of adopted contents. At the same time, the goal is also to determine whether there have been some changes in the level of representation of ecological contents in the curricula in the younger grades of primary school during the research period.

Within the framework of thus formulated research objectives, methodologically elaborated results, and operational projections can be used in modeling adequate programs in which ecological contents would be represented, thus providing better basics for more efficient organization of ecological education of students in lower primary school grades.

As previously stated, the first task is to analyze the representation of ecological contents in the curricula in junior primary school, as well as the degree of representation of ecological contents that are implemented within the curricula in junior primary school, according to teachers.

The second task is to determine which ecological contents should be included in the curricula of ecological education of students in junior primary school and what are the attitudes and opinions of the teachers about it.

\subsection{Methods and organization of research}

In the realization of the set goal and research tasks related to determining the structure and level of representation of certain ecological contents, we have chosen the most suitable descriptive method for drawing certain conclusions based on collected and arranged data. The problem of the research of ecological contents influenced the selection of adequate research instruments - the sum of the three-step and five-step scale of the Likert type (the reliability of the scale was determined using the Kronbach Alpha quotient) and a questionnaire on the attitudes and opinions of the teachers on the representation of ecological contents in younger grades of primary school.

Bearing in mind the subject matter and research tasks, we have defined a stratified random sample that best suits the nature of the subject matter and the tasks of this research. By it we made possible the representation of certain subgroups of the population, which, according to basic variables in our sample, resembles the basic set from which all was derived. The sample of this study exceeds $20 \%$ of the basic set from which it was taken. In the 2005 research, a scale on the attitudes and opinions of teachers on the degree of representation of ecological contents in the curricula involved 174 teachers, employed in primary schools in Vranje, Nis and Belgrade. The second survey was carried out in 2017 (in cooperation with students of master studies at the Pedagogical Faculty in Vranje), with a group of 48 interviewed teachers in the territory of the municipality of Doljevac.

The method of theoretical analysis has found application in this research, since it initiates an analysis of curricula, textbooks and manuals on nature and society.

\section{ANALYSIS AND INTERPRETATION OF RESEARCH RESULTS}

In order to provide conditions for the development of adequate curricula in which ecological contents would be represented, we have started the research in order to find out what is the prevalence of ecological contents in classes junior primary school, whether there has been an increase of ecological contents in relation to the twelve-year period from the first conducted research and which ecological contents should be included in the programs of ecological education of students. 
The intention was, in addition to representing ecological contents in teaching, to find out which ecological contents are represented in the curriculum of ecological education and which influence the training of students for the preservation of nature and the immediate environment.

Young people can become familliar with ecological contents in their family, preschool institutions, in schools as part of regular classes, but also in extracurricular activities and departments. That is why the question is raised: "To what extent are ecological contents represented in the curriculum?"

Research in 2005.

Table 1 Representation of organic contents in the curricula

\begin{tabular}{lrr}
\hline $\begin{array}{l}\text { Representation of organic content } \\
\text { in the curricula }\end{array}$ & $\begin{array}{r}\text { The number and percentage } \\
\text { of surveyed teachers }\end{array}$ \\
\hline Small & 140 & $80,46 \%$ \\
Enough & 34 & $19,54 \%$ \\
Are not represented & 0 & $0,00 \%$ \\
In total & 174 & $100,00 \%$ \\
\hline
\end{tabular}

A large and statistically significant majority of teachers think that the representation of ecological contents in primary school textbooks is small, $p<0.001$, and less than a fifth think, that representation is sufficient.

It has been confirmed that ecological contents are not sufficiently represented in subjects from the first to the fourth grade of primary school, in the opinion of more than four fifths of all respondents.

Research in 2017.

Table 2 Views of teachers on the representation of organic contents in the curricula for nature and society

\begin{tabular}{|c|c|c|c|c|c|}
\hline Contents & $\begin{array}{c}\text { I } \\
\text { agree }\end{array}$ & $\begin{array}{l}\text { Tend to } \\
\text { agree }\end{array}$ & $\begin{array}{c}\text { I am } \\
\text { undecided }\end{array}$ & $\begin{array}{l}\text { Tend to } \\
\text { disagree }\end{array}$ & $\begin{array}{l}\text { Strongly } \\
\text { disagree }\end{array}$ \\
\hline $\begin{array}{l}\text { In the curriculum of teaching Nature and Society } \\
\text { activities in the field of ecology and environmental }\end{array}$ & $f \quad 22$ & 14 & 3 & 9 & 0 \\
\hline protection are insufficiently represented. & $\% 45,83$ & 29,67 & 6,25 & 18,75 & 0,00 \\
\hline
\end{tabular}

To this question in the survey from 2017 , the largest number of teachers $(45.83 \%)$ decided to answer completely agree and $29.67 \%$ mostly agree, indicating that the number of teachers who believe that ecological contents is insufficiently represented in the curriculum plans and programs $75.50 \%$, while according to the survey from 2005 it was $80.46 \%$. These data lead to the conclusion that in the curricula of teaching Nature and Society to date there has been no significant increase in ecological contents.

Although in the 2005 survey teachers stated that they would represent ecological contents in all subjects in junior primary school, and in 2017 only in the Nature and Society case, we believe that there is still a justifiable possibility of such a comparison. Namely, having in mind the contents envisaged in curricula, i.e. that the ecological contents are mostly represented in the Nature and Society case and that the representation in it almost implies representation in the curriculum of all subjects in junior primary 
school, we concluded that the significant progress during the twelve years in this plan, unfortunately, did not occur.

Table 3 The extent of environmental contents are carried out in the framework of programs in departmental communities (2005)

\begin{tabular}{lcccc}
\hline Activities & $\mathrm{X}$ & $\mathrm{SD}$ & $\mathrm{n}$ & $\mathrm{Cv}$ \\
\hline Reforestation & 3,75 & 1,48 & 147 & 39,35 \\
Decorating and Landscaping & 2,67 & 1,24 & 153 & 46,33 \\
Collecting waste & 2,91 & 1,27 & 147 & 43,47 \\
Students' participation in conservation patrols & 3,48 & 1,48 & 145 & 42,41 \\
Monitoring changes in nature & 2,50 & 1,35 & 150 & 53,99 \\
Participation of students in environmental sections & 2,91 & 1,46 & 145 & 50,07 \\
Talking to government, community and sections on environmental issues & 1,97 & 1,28 & 155 & 64,86 \\
Essays and written composition prize in ecology & 2,58 & 1,36 & 154 & 52,66 \\
Preparation of photo exhibitions and literary works & 2,83 & 1,35 & 149 & 47,76 \\
\hline
\end{tabular}

The most powerful activity is conversation in the departmental community and sections on the protection of the environment, statistically more pronounced than all other individually $(\mathrm{p}$ $<0.001)$. The following is changes in nature, but it is statistically more pronounced than organizing exhibitions of photographs and writing literary works, participation of students in environmental sections $(\mathrm{p}<0,05)$, as well as from the collection of waste material $(\mathrm{p}<0.05)$, participation of pupils in patrols for preserving nature and afforestation actions $(\mathrm{p}<0.001)$. In general, in activities that are mostly "passive" type, classroom-related, conversation are more prominent, while there are statistically significantly less concrete actions, such as environmental patrols and afforestation actions.

All these results indicate that, regardless of the changes in teacher's functions, who increasingly turns into an organizer, manager and coordinator of the educational process, the role of teachers in the implementation of ecological contents has a specific meaning; especially when it comes to extracurricular activities within the departmental community and its sections.

Table 4 Involvement of students in ecological and environmental activities at school (2017)

\begin{tabular}{|c|c|c|c|c|c|c|c|}
\hline \multirow[b]{2}{*}{ Contention } & & \multicolumn{5}{|c|}{ The level of agreement with the statement } & \multirow[b]{2}{*}{$\begin{array}{l}\text { The index } \\
\text { value of } \\
\text { the rock }\end{array}$} \\
\hline & & $\begin{array}{c}\mathrm{I} \\
\text { agree }\end{array}$ & $\begin{array}{l}\text { Tend } \\
\text { to } \\
\text { agree }\end{array}$ & Undecided & $\begin{array}{l}\text { Tend to } \\
\text { disagree }\end{array}$ & $\begin{array}{l}\text { Strongly } \\
\text { disagree }\end{array}$ & \\
\hline The school does not organize & $f$ & 42 & 4 & 2 & 0 & 0 & 4,83 \\
\hline reforestation. & $\%$ & 87,5 & 8,33 & 4,17 & 0,00 & 0,00 & \\
\hline Students participating in planning & $f$ & 44 & 4 & 0 & 0 & 0 & 4,91 \\
\hline $\begin{array}{l}\text { and maintenaning of greenery in } \\
\text { the classroom and the schoolyard. }\end{array}$ & $\%$ & 91,67 & 8,33 & 0,00 & 0,00 & 0,00 & \\
\hline Students participating in the & $f$ & 27 & 15 & 6 & 0 & 0 & 4,43 \\
\hline collection of waste materials. & $\%$ & 56,25 & 31,25 & 12,5 & 0,00 & 0,00 & \\
\hline Students participating in & $f$ & 26 & 13 & 9 & 0 & 0 & 4,35 \\
\hline environmental patrols. & $\%$ & 54,17 & 27,08 & 18,75 & 0,00 & 0,00 & \\
\hline Students writing papers and & $f$ & 43 & 5 & 0 & 0 & 0 & 4,89 \\
\hline compositions on themes of ecology. & $\%$ & 89,58 & 10,42 & 0,00 & 0,00 & 0,00 & \\
\hline
\end{tabular}


By looking at Table 4 from 2017, it can be concluded that nothing changed in relation to the period of 2005 (Table 3). There are still all activities of "passive type" related to the classroom, conversation, while concrete actions are present to a lesser extent.

Starting from the assumption that ecological contents are not sufficiently represented in the programs and textbooks of primary school, in 2017 the respondents were asked the following question: "Which of these contents should be represented in the ecological education curriculum? " On this occasion, the ability to express the degree of importance of proposed activities was provided by using in the scale from 1 to 5 , where 1 marks the highest degree.

Table 5 Activities for students to be included in the curriculum of enviromental education (2017)

\begin{tabular}{|c|c|c|c|c|}
\hline Activities & $\mathrm{X}$ & $\mathrm{SD}$ & $\mathrm{n}$ & $\mathrm{Cv}$ \\
\hline Getting to know the result of the negligent attitude of man to nature & 1,85 & 1,45 & 171 & 78,53 \\
\hline Activities related to the protection of environment & 1,99 & 1,42 & 172 & 71,43 \\
\hline The benefits of reforestation of deforested areas & 2,38 & 1,38 & 170 & 58,13 \\
\hline What are they and how the resulting Acid rain & 2,63 & 1,23 & 168 & 46,61 \\
\hline What is a greenhouse - causes and consequences related to her & 2,57 & 1,28 & 164 & 49,79 \\
\hline What are the consequences of ozone depletion & 2,11 & 1,43 & 168 & 67,92 \\
\hline What are the dangers of nuclear electrons & 2,33 & 1,47 & 163 & 63,38 \\
\hline Preventive measures to combat forest fires & 2,38 & 1,35 & 167 & 56,85 \\
\hline Dangerous carcinogens & 2,11 & 1,42 & 169 & 67,54 \\
\hline What are the main air pollutants and how should they be dealt with & 1,99 & 1,46 & 168 & 73,12 \\
\hline What are the harmful effects of excessive noise & 2,31 & 1,34 & 167 & 58,06 \\
\hline What is the cause of so-called algal bloom & 2,87 & 1,22 & 163 & 42,75 \\
\hline What are the sources of harmful radiation in the household and how to & 2,13 & 1,44 & 168 & 67,66 \\
\hline alleviate the radiation of packaging and what to do during its removal & 2,22 & 1,42 & 170 & 63,93 \\
\hline What are the reserves of fresh water and where are its largest reserves & 1,98 & 1,42 & 168 & 71,87 \\
\hline What are chemical pollutants & 2,01 & 1,26 & 168 & 62,49 \\
\hline What are mechanical water pollutants & 2,16 & 1,28 & 166 & 59,31 \\
\hline Basic characteristics and hazards of radioactive waste & 2,21 & 1,30 & 166 & 58,88 \\
\hline $\begin{array}{l}\text { Organizations that exist in the world and deal with the protection of the } \\
\text { environment }\end{array}$ & 2,60 & 1,30 & 167 & 49,99 \\
\hline $\begin{array}{l}\text { Organizations that exist in your town and deal with environmental } \\
\text { protection }\end{array}$ & 2,41 & 1,35 & 167 & 55,75 \\
\hline
\end{tabular}

Teachers have shown that preference is given to fundamental contents over specific ones. Namely, the most important thing is to present the consequences of negligent attitude towards nature, which happens statistically significantly more often than other issues among which are mezzanine pollutants of fruit, characteristics and harmfulness of radioactive waste, as well as the method of determining $(\mathrm{P}<0.05)$, harmful consequences of excessive noise, danger of nuclear electrons $(\mathrm{p}<0.01)$, preventive measures for combating forest fires $(\mathrm{p}<0.001)$.

In addition to getting to know the consequences of negligent attitude to nature, the priority is given to getting acquainted with freshwater reserves, basic air pollutants and their removal and environmental protection activities. On the other hand, concrete activities are significantly less prevalent than theory. This is due to the fact that they are already present in the current programs. 
The obtained results indicate that while the curriculum is being prepared, teachers are planning ecological contents, but it is evident that there is not enough ecological contents in the course of teaching of nature and society. Therefore, it is the teacher's duty to compensate, where possible, the lack of ecological contents in the curriculum by incorporating certain ecological contents into the teaching units of all subjects.

\section{CONCLUSION}

In this research we were interested in the representation of ecological contents in teaching lower grades in primary school, through the attitudes and opinions of the interviewed teachers.

Based on their analysis and assessment of the curricula in junior primary school grades, it can be concluded that ecological contents education for environmental protection are insufficiently represented.

In the paper itself, it was insisted on the attitudes and opinions of teachers on ecological education of students, especially when it comes to the representation of ecological contents on the environment in primary school subjects and ecological contents that should be included in the curricula of ecological education of students.

As we have assumed, ecological contents are not sufficiently represented in the programs and textbooks of the primary school, which was shown and confirmed by this research.

Modern ecological situation requires standards of knowledge and skills regarding ecology to be made at a national level, as part of teaching subjects where ecological contents are present. Education system and education itself should have a permanent function of forming ecological knowledge with students.

The field of environmental protection is one of the basic postulates of the country's national interests, pointing out that the only fundamental change in human relations towards the environment provides further progress of human society. The most important role in this process is education with the aim of protecting the environment. Regardless of the fact that in the system of education ecology is not represented as a separate subject, there is a continuity in the study of ecological contents from preschool age to the end of elementary education. How much ecological contents will be represented in electoral, free and optional activities depends largely on the affinities and interests of individual teachers, as well as the school as a whole.

Individual knowledge about educational practice must be theoretically designed, interconnected, shared, raised to a higher level of knowledge in the form of theoretical attitudes and systems in order to improve the curriculum contents of ecological education and education of students in the lowest grades of primary school.

Although this research included an important segment of pedagogical work - the representation of ecological contents in the teaching in junior primary school, our satisfaction would be even greater if the findings of this research sparked new interests for further research in this field. 


\section{REFERENCES}

Andevski, М. (1997). Увод у еколошко образовање [Introduction to environmental education]. Novi Sad: Filozofski fakultet.

Angelus, J. (2004). Obrazovanje o životnoj sredini na putu ka evropskim standardima [Environmental education towards European standards]. Beograd: Ecolibri-Bion.

Vilotijević, M. (1999). Didaktika [Didactics]. Beograd: Učiteljski fakultet.

A group of American authors (1992). Kako deca mogu spasiti zemlju [How kids can save the earth]. Beograd: Studio Angel.

Đorđević, V. (1997). Васпитање и образовање за заштиту и унапређење животне средине[Еdисаtion for the protection and improvement of the environment]. Beograd: Prosvetni pregled.

Đorđević, M., Rancic, A., Krulj, R., at all (1994). Kako uspešno vaspitavati [How to successfully educate]. Niš: "Gradina".

Klemenović, J. (2007). Filozofsko-etičko utemeljenje ekološkog vaspitanja i obrazovanja - drugi deo [Philosophicalethical foundation of ecological education - second part]. Pedagogija [Pedagogy], LXII (3) 374-384.

Kozlov, N.O., Glazačev, N.S. (1998). Gumanizaciâ ékologizaciâ in education: trends and prospects, Environmental Culture and Education: oryt Russia and $\hat{U}$ ugoslavii, Moscow: Horizon.

Mitic, Lj. (2006). Didaktičko-metodičke osnove i osobenosti ekološkog vaspitanja i obrazovanja u osnovnoj školi [Didactic and methodical basics and characteristics of environmental education in elementary school] (Master degree). Vranje: Učiteljski fakultet.

Nedeljkovic, M. (2005). Pozicija i funkcija ekološkog vaspitanja i obrazovanja u kurikulumskim promenama [Position and function of ecological education in the curricular changes]. Zbornik radova sa naučnog skupa Šovek i radna sredina ", Zaštita radne i životne sredine u sistemu nacionalnog i evropskog obrazovanja“ [Proceedings of the International Conference Man and the working environment "Protection of working and living environment in the national and European education']. Niš: Fakultet zaštite na radu.

Nikolić V. (2003). Obrazovanje i zaštita životne sredine [Education and environmental protection]. Beograd: Zadužbina Andrejević.

Haeckel, E. (1866). Generalle Morphologie der Organismen. Berlin, pg 20.

Joseph, R. De Jardin. (2006). Ekološka etika, Uvod u ekološku filozofiju [Environmental Ethics, Introduction to ecological philosophy]. Beograd: Službeni glasnik.

Strbac, B., Segedinac, D. \& Vojinović-Miloradov, M. B. (2003). Motivisanost učenika za usvajanje nastavnih sadržaja iz oblasti zaštite i unapređenja ćivotne sredine u osnovnom i srednjem obrazovanju [Pupils' motivation for learning teaching contents from the field of protection and improvement of the environment in primary and secondary education], Pedagoška stvarnost [Educational Reality], 1-2, 49.

\section{ZASTUPLJENOST EKOLOŠKIH SADRŽAJA U OBRAZOVANJU I VASPITANJU U MLAĐIM RAZREDIMA OSNOVNE ŠKOLE}

Predmet ovog istraživanja su zastupljenost ekoloških sadržaja u nastavi u mlađim razredima osnovne škole i ona ima ne samo praktičnu primenu, već i teorijsku. Ekološki sadržji u nastavi u mlađim razredima osnovne škole, usmereni su ka obrazovanju učenika i njihovom razvoju za unapređenjem neposredne životne sredine. Da bi se uspešno pristupilo unapređenju i usavršavanju nastave u mlađim razredima osnovne škole, vezano za ekološke sadržaje, potrebno je prvenstveno ispitati $i$ utvrditi koliko su u našim školama ekonomski sadržaji zaista zastupljeni. Cilj i zadatak istraživanja bio je da ukaže na važnost ekoloških sadržaja i na njihovu zastupljenost u nastavi $u$ mlađim razredima osnovne škole. U skladu sa tim, u radu je predstavljen deo istraživanja koji pokazuje šta učitelji misle o zastupljenosti ekoloških sadržaja u nastavi. Istraživanjem je pokazano da se radi o veoma aktuelnoj temi.

Ključne reči: ekološki sadržaji, ekološko obrazovanje, životna sredina, učitelj. 